\title{
Establishment of Staphylococcus warneri in the Digestive Tract of Germ-Free Chicks and Isolation of the Bacterial Plasmid
}

\author{
Chieko Hoshino, Yukiko Shimizu, Kunitomo W atanabe ${ }^{*}$, \\ Nobuhiro Niwa, Mitsuhiro Furuse, Tatsuo Muramatsu, \\ Junichi Okumura, Shoichi Shimizu and Kunio OhmiYa** \\ School of Agriculture, Nagoya University, Chikusa-ku, Nagoya-shi 464-01 \\ * School of Medicine, Gifu University, Gifu-shi 500 \\ ** Faculty of Bioresources, Mie University, Tsu-shi 514
}

(Received August 27, 1990)

\begin{abstract}
The anaerobic bacterium stimulating cellulose degradation of $R$. albus $F-40$ was identified as Staphylococcus warneri based on the results of gram-staining, fermentation tests and DNA-DNA hybridization. S. warneri was found to establish itself in the digestive tract of germ-free chicks but $R$. albus was not. One plasmid $(7.7 \mathrm{kbp})$ denoted as pSW 1 was isolated from S. warneri and characterized.
\end{abstract}

Anim. Sci. Technol. (Jpn.) 62 (3) : 284-289, 1991

Key words : S. warneri, gnotobiotic chick, plasmid

According to a review written by Mitsu$\mathrm{OKA}^{6}{ }^{6}$, some microflora inhabiting the digestive tract of chicks may accelerate the host growth and others may disturb it. There, the balance of both microflora should be very important to enhance the growth of chicks. This idea is derived from many studies on microflora in the digestive tract of chicks.

However, of these studies, only a couple of papers ${ }^{13,14}$ describe the finding of cellulosedegrading microorganisms in the cecal of chicks, some of which digest cellulosic fiber in feed, but the resulting products are too small to be a sufficient energy source for the host chicks. Moreover, no study has ever proven how to improve the digestibilities of cellulosic materials via microorganisms which inhabit the chicks tract. In order to achieve this, we have to find or breed potent bacteria which can inhabit the chicks tract and improve the cellulose digesting ability of chicks. In this paper, we describe the establishment of
Staphylococcus warneri in the digestive tract of germ-free chicks and the isolation of a bacterial plasmid to improve the bacterial function genetically.

\section{Materials and Methods}

In order to identify the bacterium, the catalase test, Gram-staining test, fermentation test and DNA-DNA hybridization test were carried out. The catalase test was done by adding several colonies of the bacterium in $3 \% \mathrm{H}_{2} \mathrm{O}_{2}$ solution. After Gram-staining, the morphology of the bacterium. was observed by microscope. Fermentation properties of Staphylococci were determined with Apistaph and Apizyme (API SYSTEM S.A.). DNA hybridization test was performed with Southern blot analysis ${ }^{11)}$ using biotin labelling reactions.

Two kinds of chromosomal DNA from $S$. warneri and $R$. albus $\mathrm{F}-40$ were prepared via the method of SAIro and MiUrA ${ }^{8)}$. Plasmid DNA were prepared via the method of 


\section{Establishment of S. Warneri in Chick}

BIRNBOIM-Doly" ${ }^{1)}$.

A strictly anaeobic and cellulolytic bacterium $R$. albus $\mathrm{F}-40$ was cultivated in an anaerobic medium containing yeast extract and ball-milled cellulose or cellobiose at $37^{\circ} \mathrm{C}$ for $19-43 \mathrm{~h}^{7}$. A facultative anaerobe $S$. warneri was cultivated on trypticase soy broth (BBL Microbiology Systems) at $37^{\circ} \mathrm{C}$ for $19 \mathrm{~h}$.

The separation and molecular weight evaluation of DNA longer than $1 \mathrm{kbp}$ fragments were performed by electrophoresis with agarose gel $(0.7-1.5 \%)$ using the method of Sharp et $a l^{10}$, and this electrophoretic analysis were done with polyacrylamide gel (5\%) for DNA smaller than $1 \mathrm{kbp}$ via the method of Maniatis et al. ${ }^{5)}$. DNA fragments on the gel were detected with fluorescent light emitted by the short UV waves af ter ethidium bromide staining.

Southern blot analysis was conducted to identify the bacterium. For preparing the DNA probe, a biotin-labelling reaction was carried out using a nick translation kit (Takara) with the presence of biotin-7-dATP according to the protocol from the supplier. DNA fragments completely cleaved with restriction nucleases were separated by electrophoresis with $0.8 \%$ agarose slab gel and blottransferred on the Hybond ${ }^{\mathrm{TM}}-\mathrm{N}$ membrane (Amersham), hybridized with the probe and detected subsequently by Blue GENE ${ }^{\mathrm{TM}}$ for non radioactive nucleic acid detection.

For determining the plasmid copy number, the chromosomal and plasmid DNA extrcted were quantitatively analyzed on an agarose gel electrophoretogram. The amount of each DNA on the electrophoretogram was measured with a scanning densitometer (DUAL-WAVE LENGTH TLC SCANNER CS-910, SHIMADZU) coupled to a microcomputer for peak integration. The molecular masses of chromosome were evaluated as approximately $2.6 \times 10^{9}$ daltons. The plasmid copy number (np) was calculated as follows ;

$$
\mathrm{np}=(\mathrm{Mc} \cdot \mathrm{Cp}) / \mathrm{Mp} \cdot \mathrm{Cc}
$$

$\mathrm{Mp}$ and $\mathrm{Mc}$ were the molecular masses of the plasmid and the chromosome, respectively, and $\mathrm{Cp}$ and $\mathrm{Cc}$ were the amount of plasmid and chromosomal DNA, respectively ${ }^{12)}$.

Single comb, White Leghorn chicks of mixed sexes were used, the parents of which ( $\delta$ : strain no. 09, 우: strain no. 18) were supplied by the from Gifu Prefectural Poultry Breeding Station in Japan. The experimental eggs were taken from the nest soon after laying to ensure freedom from fouling and clean eggs were selected for the production of germ-free chicks. The surface of these eggs were disinfected with formalin gas (potassium permanganate $7.1 \mathrm{~g}$ and formalin $14.3 \mathrm{~g}$ per cubic meter) for 10 min, thereafter, incubated in the disinfected incubator at $37.8^{\circ} \mathrm{C}$ for 18 days. Then, they were candled and disinfected again by spraying with peracetic acid solution (2\%). The 18 days-incubated eggs were disinfected and introduced into four cages in each disinfected plastic isolators where they were incubated to hatch at $38^{\circ} \mathrm{C}$. The humidity in the incubator was maintained at more than $70 \%$ until hatching. After hatching, one chick was left in each cage and others as well as egg shells were removed. Detailed procedures for hatching and maintaining germ-free chicks have been described elsewhere ${ }^{15)}$. The inoculum $\left(1 \mathrm{~m} l, 10^{9}\right.$ cells $\left./ \mathrm{m} l\right)$ of the mixture of $R$. albus and Staphylococcus warneri was poured with an injector having a polished needle into throat of 8 chicks of 3 days-age. Soon after inoculation, the diet disinfected by irradiation with ${ }^{60} \mathrm{Co}$ at $5 \mathrm{Mrad}$ and sterilized water were freely taken by chicks. The ingredients of the diet granulated were chick mash (40\%), soybean protein $(17 \%)$, cellulose $(28 \%)$, corn oil $(9 \%)$, vitamine $(1 \%)$, and mineral mixture $(5 \%)$. The viable bacterial cells in feces produced by the chicks, after $1,3,7$ and 18 days of bacterial inoculation, were detected using the media for both bacteria.

Sterility tests were undertaken at day 4 and day 12 . Three liquid media (1. trypricase soy broth, 2. thioglycollate medium without indi- 
Hoshino, Shimizu, Watanabe, Niwa, Furuse, Muramatsu, Okumura, Shimizu and Ohmiya

cator-135 C (BBL, Cockeysville, Maryland, USA) and 3. sabouraud liquid medium (Oxoid Ltd, Basingstoke, Hants) $\}$ and two agar plates (1. tryptone soya agar (Oxoid Ltd) and 2. tryptone soya agar plus yeast extract (BBL) were used ${ }^{15)}$. Liquid media were used to detect aerobes, and agar plates were used to determine both anaerobes and aerobes. The chicks were judged to be germ-free only when all these tests were negative for 2 weeks.

\section{Results and Discussion}

During the process of $R$. albus $\mathrm{F}-40$ isolation, a facultative anaerobic bacterium was isolated with the medium for anaerobes containing glucose as a main carbon source. Cellulose degradation of $R$. albus F-40 increased significantly as shown in Fig. $1-\mathrm{C}$, in which the bulk of the cellulose in the medium was decreased markedly when the isolate was cocultured with $R$. albus F-40. Therefore, we had great interest in an isolate which might be available to stimulate the cellulose-degrading ability of $R$. albus. The isolate did not solu-

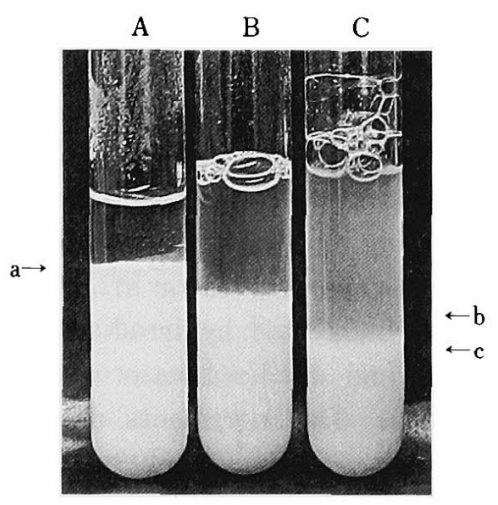

Fig. 1. Bulk changes of ball milled cellulose in an anaerobic medium caused by $R$. albus and/or the isolate. A; Medium without inoculation. B; Culture of $R$. albus only. C; Co-culture of $R$. albus and an isolated strain. Arrows $a, b$, and c show the level of bulk of ball milled cellulose after cultivation of organisms. bilize cellulose by itself but utilize glucose very well. Therefore, the stimulation phenomenon for cellulose degradation of $R$. albus by the isolate might be explained by that one strain can promote the growth of the counterpart by utilizing the fermentation products $(2,4,9)$.

The organism was catalase positive and Gram staining positive. The morphological shape of the isolate was cocci similar to $R$. albus, making it difficult to distinguish them by shape. Fermentation tests and enzyme reaction tests suggested a classification of the bacterium as Staphylococcus sp. By employing DNA-DNA hybridization the bacterium was finally identified as Staphylococcus warneri with $100 \%$ relative homology to that of authentic S. warneri, judging from the intensity of radio isotope (data not shown). S. warneri have high esterase and lipase activities and have low $\beta$-glucosidase activity (data not shown).

The co-culture of $R$. albus and $S$. warneri was inoculated into germ-free chicks via mouth. Many viable bacterial cells were detected from chick faeces, both aerobically and anaerobically, from after two days of inoculation till the end of the experiment (18 days old), indicating that organisms inhabited the chicks. At day 18, 8 gnotobiotic chicks were killed by cervical dislocation and the digestive tract was soon separated into crop, duodenum, ileum, caecum and colon, from each of which the content was suspended into media for both organisms. Viable cells in each digestive tract were counted and shown in Table 1. The Gram positive cocci were found mainly in the caecum and colon and to a lesser extent in the other digestive tract (Table 1). From the DNA-DNA hybridization test, the bacteria inhabiting the chick was identified as S. warneri, not $R$. albus F-40 (Fig. 2), revealing that only $S$. warneri was established in germ-free chicks. When only S. warneri was inoculated into germ-free chicks, similar results to those shown in Table 1 were 

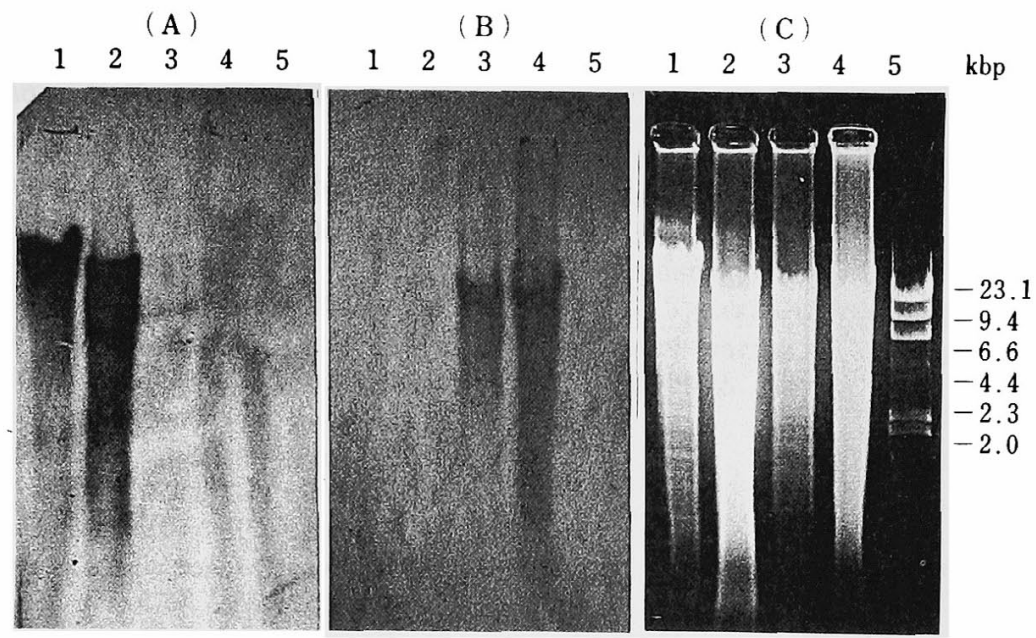

Fig. 2. DNA-DNA hybridization between the isolate from gnotobiotic chick and $R$. albus or between the isolate and $S$. warneri

(A) ; Southern blot analysis (probe; chromosomal DNA from S. warneri)

(B) ; Southern blot analysis (probe ; chromosomal DNA from $R$. albus)

(C) ; Agarose-gel electrophoretogram

Lane 1; Chromosomal DNA $(20 \mu \mathrm{g})$ from Gram-positive coccus digested with Hind III

Lane 2; Chromosomal DNA $(50 \mu \mathrm{g})$ from $S$. warneri digested with Hind III

Lane 3 ; Chromosomal DNA $(20 \mu \mathrm{g})$ from $R$. albus digested with Hind III

Lane 4 ; Chromosomal DNA $(80 \mu \mathrm{g})$ from $R$. albus digested with Hind III

Lane $5 ; \lambda$ DNA digested with Hind III

Table 1. Counts of microbial colony from the contents of crop, duodenum, ileum, caecum and colon of the gnotobiotic chicks

\begin{tabular}{|c|c|c|c|c|c|}
\hline $\begin{array}{c}\text { Gnotobiotic } \\
\text { chicks }\end{array}$ & Crof & $\begin{array}{l}\text { uode- } \\
\text { um }\end{array}$ & Ileum & Caecu & olon \\
\hline 1 & HWH & + & H & H & HI \\
\hline 2 & $H$ & + & $H$ & 世 & H \\
\hline 3 & + & + & $H$ & HWH & $\mathrm{H}$ \\
\hline 4 & + & m & $H$ & \# & $H$ \\
\hline 5 & $H$ & + & + & H & H \\
\hline 6 & $-H$ & + & + & HI & H \\
\hline 7 & + & $H$ & + & $H$ & $H$ \\
\hline 8 & + & + & + & HI & H \\
\hline
\end{tabular}

Gnotobiotic chicks were prepared from germfree counterparts by innoculating Ruminococcus albus and Staphylococcus warneri at 18 days of age

+ less than 100 colonies

H100 500 colonies

世1500 1000 colonies

HW more than 1000 colonies obtained, indicating that $S$. warneri was istablished in the digestive tract.

Via the modified SAITo-Miura method, only one plasmid was isolated from $S$. warneri, the copy number of which was evaluated to be about 10 from Fig. 3. The size of the plasmid was $7.7 \mathrm{kbp}$ and denoted as pSW 1. Pst $\mathrm{I}$, EcoR I, Pvu II and Hind III sites were located on the plasmid as shown in Fig. 4. The existence of the single plasmid in the $S$. warneri strain showed very differences of the human and nonhuman primate $S$. warneri strain which often carry 2 to 10 plasmids ${ }^{3}$. This simple plasmid system in $S$. warneri will help us to establish a novel host-vector system of Staphylococcus sp. Then it will be possible to confirm celluloysis of $S$. warneri by a gene transfer system. These results have provided a clue toward improving the cellulose-diges- 
Hoshino, Shimizu, Watanabe, Niwa, Furuse, Muramatsu, Okumura, Shimizu and Ohmiya

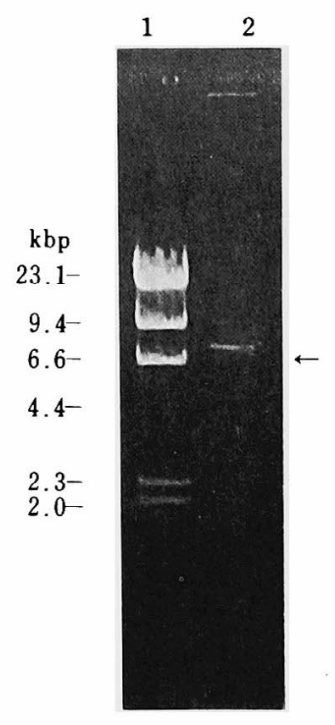

Fig. 3. Agarose-gel electrophoretograms of plasmid and chromosomal DNA from $S$. warneri.

Lane $1 ; \lambda$ DNA digested with Hind III

Lane 2; Plasmid DNA from $S$. warneri digested with Pst I

Arrow indicates a plasmid from $S$. warneri

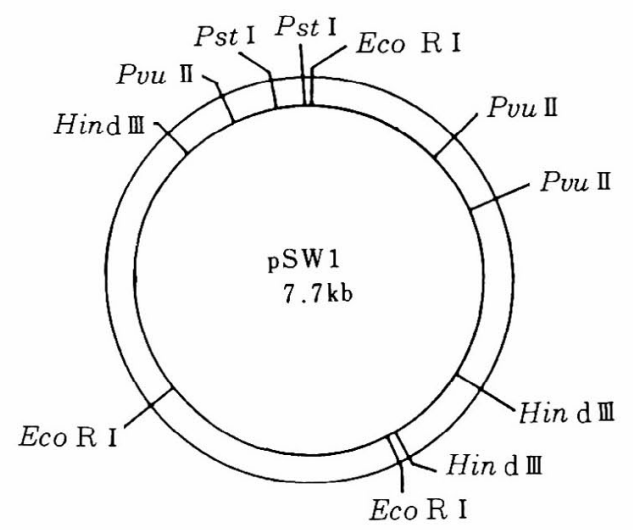

Fig. 4. Restriction map of $\mathrm{pSW} 1$ isolated from S. warneri

tibility of chicks, when the cellulase gene is integrated into the plasmid of S. warneri and expressed in a chick's digestive tract.

\section{Acknowledgment}

This work was supported in part by a grantin aid for General Scientific Research C. No. 0156309 and Developmemtal Scientific Research (2) No. 63860038

\section{References}

1) Birnboim, H.C. and J. Doly, A rapid alkaline extraction procedure for screening recombinant plasmid DNA. Nucleic Acid Res., 7 : 1513-1523. 1977.

2) Dehority, B.A. Hemicellulose degradation by rumen bacteria. Federal Proceedings, 32 : 1819-1825. 1973.

3) Kloos, W.E., B.S. Orban and D.D. WaLker, Plasmid composition of Staphylococcus species. Can. J. Microbiol., 27 : 271-278. 1980.

4) Latham, M.J. and M.J. Wolin, Fermentation of cellulose by Ruminococcus flavefaciens in the presence and absence of Methanobacterium ruminantium. Applied and Environ. Microbiol., 34 : 297-301. 1977.

5) Maniatis, T., E.F. Fitch and J. Sambrook, "Molecular Cloning", a laboratory manual. 173-178. Cold Spring Harbor Laboratory. New York. 1982.

6) Miтsuoka, T., Intestinal flora of chikens. J. Jpn. Soc. Poultry Disease, 13 : 113-127. 1977.

7) Ohmiуa, K., K. Nokura and S. Shimizu, Enhancement of cellulose degradation by Ruminococcus albus at high cellulose concentration. J. Ferment. Technol., 61: 25-30. 1983.

8) Saito, H. and K. Miura, Preparation of transforming deoxyribonucleic acid by phenol treatment. Biochim. Biophys. Acta, 72:616-629. 1963.

9) Scheifuiger, C.C. and M.J. Wolin, Propionate formation from cellulose and soluble sugars by combined cultures of Bacteroides saccinogenes and Selenomonas ruminantinm. Applied Microbiology, 26 : 789-795. 1973.

10) Sharp, P.A., B. Sugden and J. Sambrook, Detection of two restriction endonuclease activities in Haemophilus parainfluenzae using agarose-ethidium bromide electrophoresis. Biochemistry, 12: 3055. 1982. 
11) SouTHern, E.M., Detection of specific sequences among DNA fragments by gel electrophoresis. J. Mol. Biol., 98 : 503-517. 1975.

12) Steven, J.P., S. Carleton and R.P. Novick, Determination of plasmid copy number by fluorescence densitometry. Plasmid., 9: 182-190. 1983.

13) Thornburn, C.C. and J.S. Willcox, The caeca of the domestic fowl and digestion of the crude fiber complex. I. Digestibility trials with normal and caecectomised birds. Brit. Poult. Sci., 6 : 23-31. 1965.

14) Thornburn, C.C. and J.S. Willicox, The caeca of the domestic fowl and digestion of the crude fiber complex. II Experiments in vivo with tistulated birds, and the artificial and isolated caecum in vitro. Brit. Poult. Sci., 6 : 33-43. 1965.

15) Yokota, H., M. Furuse, J. Okumura and I. TASAKI, A simple method for production and rearing of the germ-free chick. Jpn. J. Zootech. Sci., 55 : 600-603. 1984.

\title{
Staphylococcus warneri の無菌鶏七ナ消化管への 定着とそのプラスミドの単離
}

\author{
星野智恵子・清水由希子・渡辺邦友 ${ }^{*}$ 丹丹羽信裕・古瀬充宏 \\ 村松達夫・奥村純市・清水祥一・大宮邦雄 ${ }^{* *}$ \\ 名古屋大学農学部，名古屋市千種区 464-01 \\ *岐皁大学医学部, 岐皁市 500 \\ **三重大学生物資源学部，津市 514
}

嫌気条件下でグルコースを資化するグラム陽性の通性嫌気性球䒩の一種は，セルロース資化能を全く 持たないが $R$. albus と混合培養するとR. albus のせルロース分解能を高めた．そこで分離菌株の グラム染色, 各種の糖の発酵能, および各種酵素活性を調べた結果, Staphylococcus sp. であること が判明した，さらに本菌の DNA を近縁株約 30 種の DNA と八イブリダイゼーションを行ない，S. warneri と同定した．本菌の培養液を R. albus の培養液とともに無菌のヒナに 1 回だけ経口注入し たところ，2日目より実験期間中常にS. warneri のみがフン中に検出された．18日踰になった時に 全七ナ腸管を摘出し, 内容物中の生菌を調べたところ, 盲腸と結腸にS. warneri が著しく定着して いた．しかし，R. albusは全く検出できなかった．この結果，R. albus はヒナに定着しないが，S. warneri は定着することが判明した，本菌のプラスミドをBirnboim-Doly 法により検索したところ，

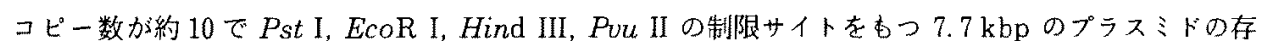
在を確認し,これを $\mathrm{pSW} 1$ と命名した。 